\title{
Sumber Penyumbang Karbon ke dalam Sedimen Dataran Rumput Laut di Muara Sungai Pulai, Johor, Malaysia
}

(Source Contributors of Carbon to Sediments in the Seagrass Meadows of Sungai Pulai Estuary, Johor, Malaysia)

\author{
Nur HidAYAH, MOHAMMAd ROZAIMI* \& MOHD SHAHRUl MOHD NADZIR
}

\begin{abstract}
ABSTRAK
Terdapat banyak kajian karbon biru yang menggunakan kaedah penjejak isotop untuk mendapatkan maklumat mengenai sumbangan sumber bahan organik (OM) di dalam sedimen. Objektif kajian ini terbahagi kepada dua iaitu untuk mengetahui sumbangan sumber kepada takungan om dan untuk membandingkan keberkesanan penggunaan dua jenis isotop stabil $\left(\delta^{13} \mathrm{C}\right.$ dan $\left.\delta^{15} N\right)$ atau satu jenis isotop stabil $\left(\delta^{13} C\right)$ dalam menentukan sumbangan om di kawasan persampelan. Sampel rumput laut, makroalga, seston dan epifit di kawasan muara Sungai Pulai dianalisis dan diukur menggunakan jisim aliran nisbah isotop (IRMS). Analisis isotop stabil melalui $R$ (SIAR) pula digunakan untuk menganggarkan sumbangan relatif keempat-empat sumber tersebut kepada takungan om sedimen. Sampel seston mencatatkan nilai tertinggi (53 98\%) dan rumput laut mencatatkan nilai terendah (7\%) dalam sumbangan om di dalam sedimen dataran rumput laut. Ini menunjukkan sumber luar (aloktonus) memainkan peranan yang penting kepada penambahan zarah terampai. Menggunakan dua penjejak isotop stabil, plot kepadatan menunjukkan sumbangan yang lebih kecil oleh seston (96.18 - 99.82\%) berbanding menggunakan satu penjejak isotop stabil (89.15 - 99.75\%). Terdapat perbezaan bererti $(p<0.05)$ antara nilai julat peratus kebolehpercayaan (C195\%) penggunaan dua penjejak isotop stabil ( $\delta^{13} \mathrm{C}$ dan $\left.\delta^{15} \mathrm{~N}\right)$ dan nilai julat peratus kebolehpercayaan (C195\%) penggunaan satu penjejak isotop stabil $\left(\delta^{13} \mathrm{C}\right)$. Hal ini menunjukkan nilai julat peratus kebolehpercayaan (C195\%) penggunaan dua penjejak isotop stabil lebih kecil iaitu bermaksud kebolehpercayaan adalah lebih tinggi melalui kaedah ini dalam pemodelan sumbangan sumber om di kawasan kajian.
\end{abstract}

Kata kunci: Bahan organik; isotop stabil; model pencampuran Bayesian; SIAR

ABSTRACT

There are many blue carbon studies using isotopic tracer methods to obtain information on the source contribution of organic materials $(O M)$ in the sediment. The objectives of this research were to identify the sources contributing to the sediment OM pool, and to compare the reliability of using dual stable isotopes $\left(\delta^{13} \mathrm{C}\right.$ and $\left.\delta^{15} \mathrm{~N}\right)$ or single stable isotope $\left(\delta^{13} C\right)$ in determining the source contributions of oM in the sampling area. Seagrass, macroalgae, seston and epiphyte samples in Sungai Pulai estuary were analyzed and measured using isotopic ratio mass spectrometry (IRMS). The relative contribution of the four sources to the OM pool sediment was estimated by using Stable Isotope Analysis in $R$ (SIAR). Seston recorded the highest value (53 - 98\%) and seagrass recorded the lowest value (7\%) in oM contribution in the sediments of the seagrass meadow. This shows that external input (allochthonous) plays an important role in the addition of suspended particles. By using dual stable isotope tracer, density plots showed a smaller range of contribution by seston $(96.18$ - 99.82\%) than using a single tracer (89.15 - 99.75\%). There is a significant difference $(p<0.05)$ between the value of the reliability percentage range (C195\%) using dual stable isotope tracer $\left(\delta^{13} \mathrm{C}\right.$ and $\left.\delta^{15} \mathrm{~N}\right)$ than using a single tracer $\left(\delta^{13} C\right)$. This showed that the value of the reliability range (C195\%) using dual stable isotope tracer is smaller and therefore the realibility is higher in the modelling of source contributions of OM in the study area.

Keywords: Bayesian mixing model; organic matter; SIAR; stable isotope

\section{PENGENALAN}

Bahan organik di perairan air terkepung boleh dibahagikan kepada dua jenis asalan iaitu aloktonus dan autotonus (Krull et al. 2009). Bahan organik autotonus boleh dibahagikan kepada beberapa punca primer sebagai tambahan kepada fitoplanton seperti angiosperma akuatik (termasuk rumput laut) dan makroalga. Karbon yang terkumpul di dataran rumput laut pula terdiri daripada bahan-bahan autotonus, bahagian bahan rumput laut (daun, akar dan rhizom) yang dihasilkan dan termendap in-situ, serta bahan-bahan aloktonus (rumput rawang, makroalga, diatom bentos, fitoplankton, dan seston) yang termendap di dalam sedimen (Bouillon \& Boschker 2006; Gacia \& Duarte 2001; Kennedy et al. 2010). Kemudian, karbon yang tersekuester akan melalui proses tertentu termasuk penyimpanan karbon dalam sedimen, penyerapan karbon dalam lajur air, dan pertukaran $\mathrm{CO}_{2}$ antara udara dan laut.

Dataran rumput laut merupakan sistem yang sangat produktif yang menghasilkan sejumlah besar karbon organik. Walau bagaimanapun, jumlah dan kadar karbon 
organik yang terkumpul dalam sedimen rumput laut sering melebihi jumlah karbon yang dihasilkan oleh rumput laut dan ini menunjukkan bahawa terdapat sumber daripada luar yang menyumbang kepada stok karbon dalam sedimen rumput laut (Duarte \& Cebrián 1996; Duarte et al. 2010, 2005; Gacia et al. 2002).

Berdasarkan kajian terdahulu, analisis $\delta^{13} \mathrm{C}$ bahan organik di dalam sedimen menunjukkan tisu rumput laut sebagai penyumbang utama kepada simpanan karbon dalam sedimen di bawah kanopi rumput laut (Kennedy et al. 2010; Smit et al. 2005). Secara global, diangggarkan bahawa rumput laut menyumbang kepada $\sim 50 \%$ karbon di dalam sedimen dataran rumput laut dan separuh lagi disumbangkan oleh sumber bukan rumput laut seperti fitoplankton, tumbuhan daratan, dan alga (Kennedy et al. 2010). Meskipun begitu, masih tidak jelas sama ada karbon yang tersimpan di dalam dataran rumput laut berasal daripada sumber yang sama dengan yang disimpan di dataran rumput laut semula jadi ataupun tidak.

Telah diketahui umum bahawa sistem marin sememangnya kompleks dan kajian penyurih isotop telah digunakan secara meluas selama beberapa dekad yang lalu untuk memahami sumber dan laluan arus bahan organik dan lautan (Fry \& Sherr 1984; Lee et al. 2012). Menurut Fry dan Sherr (1984), nisbah isotop karbon digunakan sebagai penunjuk sumber bahan organik. Terdapat beberapa jenis model pencampuran Bayesian yang sering digunakan. Antaranya ialah MixSIAR (Stock \& Semmens 2016), IsoSource (Phillips \& Gregg 2003), IsoWeb (Kadoya et al. 2012) dan juga SIAR (Parnell et al. 2010). MixSIAR digunakan untuk menganalisis data penyurih biologi (isotop stabil, asid lemak), yang menggangar peratus perkadaran sumbangan sumber kepada campuran populasi, manakala IsoSource ialah model percampuran isotop untuk pemetakan jumlah sumber yang berlebihan. Antara contoh pemetakan yang dianalisis oleh IsoSource ialah sumber makanan di dalam diet haiwan, sumber karbon di dalam bahan organik tanah dan banyak lagi (Benstead et al. 2006). Model pencampuran IsoWeb pula mengganggar perkadaran diet untuk semua pengguna di dalam jaringan makanan berdasarkan maklumat isotop stabil.

Banyak kajian mengenai karbon biru yang menggunakan perisian SIAR untuk mengetahui sumber dan penanda isotop stabil (Watanabe \& Kuwae 2015) kerana ia mesra pengguna dan juga penggunaannya yang luas dalam perisian R. Pada masa kini, terdapat perincian bagi menerangkan tentang penggunaan SIAR (https://www.tcd. ie/Zoology/research/groups/jackson/projects/Rpodcasts. php). Maka, ini memudahkan penggunaan perisian SIAR dalam kajian masing-masing. Meskipun model percampuran isotop stabil ini pada kebiasaannya digunakan untuk kajian ekologi dan biologi yang melibatkan pembentukan semula pemakanan (diet) haiwan, namun kegunaannya telah dipelbagaikan termasuklah digunakan untuk mengesan sumber di dalam sedimen, mengenal pasti sumber pencemaran dan mengesan sumber air (Phillips et al. 2012, 2005).
Meskipun terdapat banyak cara dan perisian yang boleh digunakan untuk menentukan nilai sumber karbon di dalam sedimen namun isu penggunaan satu atau dua jenis isotop stabil masih menjadi persoalan (Parnell et al. 2010). Beberapa prosedur lelaran telah digunakan beberapa kajian dalam menentukan had penyumbangan sistem tiga sumber dengan satu isotop stabil (Dauby 1989; Zencich et al. 2002) atau sistem yang lebih daripada 3 sumber dengan penggunaan dua isotop stabil (Minagawa 1992). Tambahan lagi, penggunaan satu stabil isotop sahaja $\left(\delta^{13} \mathrm{C}\right.$ atau $\delta^{15} \mathrm{~N}$ ) menyukarkan untuk mengenal pasti perbezaan antara sumber (Briand et al. 2015). Ini disebabkan oleh pertindihan perkadaran di dalam graf plot ketumpatan. Jika nilai penanda isotop sumber adalah sama, ini akan menyukarkan data untuk diproses di dalam perisian.

Berdasarkan rujukan hasil kajian lepas, penggunaan penanda satu isotop $\left(\delta^{13} \mathrm{C}\right)$ sudah cukup cekap dan dipercayai untuk mengetahui sumber OM di dalam sedimen (Fry et al. 1977). Sebagai contoh, Lavery et al. (2013) hanya menggunakan satu isotop $\left(\delta^{13} \mathrm{C}\right)$ di dalam kajiannya untuk mengetahui karbon organik di dalam sedimen spesies rumput laut yang berbeza. Meskipun begitu, kajian tersebut hanya tertumpu dalam mencari nilai karbon organik pada sumber organik yang sama iaitu sedimen rumput laut. Oleh kerana nilai penanda isotop rumput laut berada pada julat yang sama, maka tiada pertindihan julat yang akan berlaku sewaktu data diproses, melainkan penentuan karbon organik dilakukan pada bahagian rumput laut yang tertentu. Ini kerana menurut Greiner et al. (2016), nilai isotop karbon dan nitrogen rumput laut berbeza bergantung kepada bahagian (epifit, daun, akar atau rizom) dan waktu persampelan tumbuhan itu diambil.

Namun begitu, penggunaan satu isotop sahaja selalunya tidak mencukupi untuk menyelesaikan masalah persekitaran (Peterson 1999). Hal ini kerana kebanyakan saintis mengunakan lebih daripada dua penjejak dalam menyelesaikan permasalahan percampuran yang melibatkan 4 hingga 8 sumber (Belicka \& Harvey 2009; Collins et al. 2010; Schauer et al. 1996). Sebagai contoh, Briand et al. (2015) telah menggunakan dua penanda isotop $\left(\delta^{13} \mathrm{C}\right.$ dan $\left.\delta^{15} \mathrm{~N}\right)$ untuk menentukan sumber terbesar yang menyumbang kepada bahan organik di kawasan lagun terumbu karang. Tujuan kajian ini dilakukan adalah untuk mencirikan penjejak isotop $\left(\delta^{13} \mathrm{C}\right.$ dan $\left.\delta^{15} \mathrm{~N}\right)$ terhadap potensi beberapa sumber OM di kawasan ekosistem rumput laut serta membandingkan penggunaan satu isotop stabil dan dua isotop stabil untuk mengenalpasti sumber karbon di dalam kawasan kajian.

\section{BAHAN DAN KAEDAH}

\section{KAWASAN KAJIAN}

Sampel sedimen diambil di dua kawasan iaitu di Tanjung Adang dan di Beting Merambong (Rajah 1). Lokasi kawasan kajian ini terletak di muara Sungai Pulai, Johor $\left(1^{\circ} 20^{\prime} 3^{\prime \prime} \mathrm{N} 103^{\circ} 32^{\prime} 58^{\prime \prime} \mathrm{E}\right)$. Kedua-dua kawasan kaya 
dengan taburan spesies rumput laut (Ahmad et al. 2015) dan organisma marin bentik (Ara et al. 2011; Arshad et al. 2010; Cob et al. 2014; Fairoz et al. 2018; Shi et al. 2014). Meskipun dataran rumput laut Tanjung Adang kelihatan semakin pulih akibat pembinaan pelabuhan Tanjung Pelepas namun pembangunan sedang giat dirancang untuk kawasan tersebut. Kawasan Beting Merambong pula terbahagi kepada dua bahagian iaitu Merambong Barat dan Merambong Timur. Hal ini disebabkan oleh aktiviti tebus guna yang sedang giat dijalankan (Hossain et al. 2018).

\section{TEKNIK PERSAMPELAN}

Sampel sedimen telah diambil menggunakan batang paip PVC yang berukuran $50 \mathrm{~cm}$ panjang dan berdiameter 50 $\mathrm{mm}$. Batang paip yang ditajamkan hujungnya diketuk ke dalam sedimen secara manual. Sampel diambil sewaktu air surut bagi memudahkan proses pengambilan sampel. Sebanyak tiga sampel sedimen telah diambil pada setiap stesen. Sampel kemudiannya dianalisis di makmal bagi mendapatkan nilai karbon organik dan karbon bukan organik (Hidayah et al. 2019). Bagi mendapatkan penjejak analisis isotop stabil, model percampuran Bayesian telah dilakukan dengan menggunakan empat jenis sumber bahan organik (OM) di kawasan simpanan karbon iaitu rumput laut, makroalga, epifit dan seston. Spesimen diambil di kawasan Tanjung Adang, Merambong Timur dan
Merambong Barat. Model percampuran Bayesian (perisian $\mathrm{R}$ dan pakej SIAR) (Parnell et al. 2010) digunakan untuk mentafsir kadar sumbangan setiap sumber OM ke dalam sedimen di kawasan kajian.

\section{ANALISIS SAMPEL}

Bagi analisis sampel, empat sumber OM yang terdiri daripada rumput laut, makroalga, epifit dan seston telah dipilih dan dikenal pasti (Jadual 1). Sebanyak 20 jumlah sampel rumput laut dan 9 sampel makroalga telah dipilih. Bilah daun sampel dikikis permukaannya untuk membuang segala epifit dan seterusnya dicuci dengan air suling untuk membuang segala zarah luaran yang melekat di permukaan bilah daun. Bagi epifit pula, sebanyak 4 sampel yang dikikis secara manual daripada permukaan luar daun rumput laut telah diambil. Lapan sampel seston (zarah terampai di dalam turus air) dikumpulkan dengan menapis air laut dengan menggunakan penapis seratmikro kaca (Whatman $\mathrm{GF} / \mathrm{C}$ ). Penapis seratmikro kaca tersebut telah dibakar awal pada suhu $450^{\circ} \mathrm{C}$ sebelum digunakan untuk menapis air. Sampel seston ini kemudiannya dikeringkan dan dikikis daripada permukaan penapis ini untuk proses seterusnya.

Sampel kemudiannya dibahagikan kepada dua bahagian, iaitu satu sampel menjalani proses pengasidan manakala satu lagi sampel tidak. Sampel rumput laut,

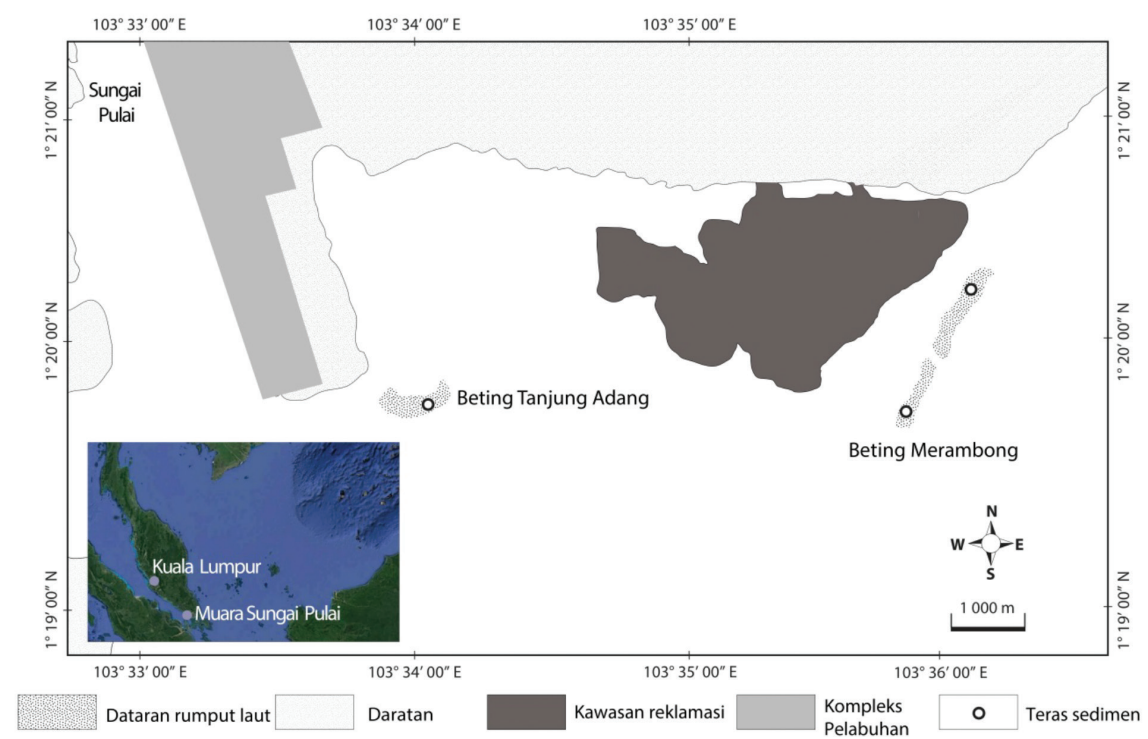

RAJAH 1. Kawasan kajian di muara Sungai Pulai

JADUAL 1. Purata sumber karbon dan nitrogen dalam sedimen (min), ralat ( \pm SD) dan saiz sampel (n) yang digunakan di dalam model percampuran Bayesian. Sumber bahan organik adalah rumput laut, seston, makroalga dan epifit di muara Sungai Pulai. Angka di dalam kurungan merujuk kepada jumlah sampel

\begin{tabular}{ccccccccc}
\hline \multirow{2}{*}{ Sumber } & \multicolumn{2}{c}{ Rumput laut (20) } & \multicolumn{2}{c}{ Seston (8) } & \multicolumn{3}{c}{ Makroalga (9) } \\
\cline { 2 - 8 } & Min & Ralat & Min & Ralat & Min & Ralat & Min & Ralat \\
\hline$\delta^{13} \mathrm{C}(\% \circ)$ & -12.5 & 1.9 & -23 & 0.3 & -21 & 3.9 & -18.2 & 1.7 \\
$\delta^{15} \mathrm{~N}(\% \circ)$ & 7.9 & 1.8 & 4.9 & 2.2 & 8.7 & 1.3 & 9.9 & 0.3 \\
\hline
\end{tabular}


makroalga, epifit dan seston menjalani proses pengasidan untuk mendapatkan nilai $\delta^{13} \mathrm{C}$ manakala sampel rumput laut, makroalga, epifit dan seston yang tidak menjalani proses pengasidan dihitung untuk mendapatkan nilai $\delta^{15}$ N. Sampel dirangkumkan sebanyak 1.5 hingga $2 \mathrm{mg}$ dan dianalisis di makmal jisim aliran nisbah isotop (IRMS, model Delta Plus XP) di Universiti Washington. Nisbah ${ }^{13} \mathrm{C} /{ }^{12} \mathrm{C}$ dinyatakan relatif kepada PeeDee Belemnite (PDB) untuk karbon. Manakala ${ }^{15} \mathrm{~N} /{ }^{14} \mathrm{~N}$ dinyatakan relatif kepada nitrogen yang terkandung pada atmosphera. Nisbah ${ }^{13} \mathrm{C} /{ }^{12} \mathrm{C}$ dan ${ }^{15} \mathrm{~N} /{ }^{14} \mathrm{~N}$ dikira sebagai:

$$
\delta^{13} \mathrm{C} \text { atau } \delta^{15} \mathrm{~N}=\left[\left(\mathrm{R}_{\text {sampel }} / \mathrm{R}_{\text {piawai }}\right)-1\right] \times 10^{3}
$$

dengan R ialah masing-masing ${ }^{13} \mathrm{C} /{ }^{12} \mathrm{C}$ atau ${ }^{15} \mathrm{~N} /{ }^{14} \mathrm{~N}$.

\section{ANALISIS STATISTIK}

Model Percampuran Bayesian (SIAR) digunakan dalam kajian ini bertujuan untuk menentukan kandungan sumbangan karbon di kawasan muara Sungai Pulai daripada empat jenis sumber karbon iaitu rumput laut, makroalga, epifit dan seston. Tambahan lagi, model percampuran isotop yang stabil dicipta untuk menganggar kadar sumber yang menyumbang kepada campuran tersebut. Model Percampuran Bayesian (SIAR) menggunakan dua jenis isotop stabil iaitu $\delta^{13} \mathrm{C}$ dan $\delta^{15} \mathrm{~N}$ untuk membandingkan kandungan sumber karbon di dalam bentuk peratus (\%). Seterusnya nilai $\delta^{13} \mathrm{C}$ dan $\delta^{15} \mathrm{~N}$ yang diperoleh diplotkan untuk menentukan kadar sumbangan setiap sumber OM terhadap sedimen di kawasan kajian.

\section{HASIL DAN PERBINCANGAN}

Hasil kajian ini menggunakan model percampuran Bayesian untuk membandingkan dua jenis isotop stabil yang berbeza iaitu $\delta^{13} \mathrm{C}$ dan $\delta^{15} \mathrm{~N}$. Graf perkadaran sumbangan sumber organik terhadap bahan organik (OM) di muara Sungai Pulai menunjukkan hasil analisis dan perbandingan antara dua isotop stabil $\left(\delta^{13} \mathrm{C}\right.$ dan $\left.\delta^{15} \mathrm{~N}\right)$ dan satu jenis isotop $\left(\delta^{13} \mathrm{C}\right)$. Bagi mengupas objektif pertama kajian, iaitu mengenai sumber karbon yang menyumbang kepada sedimen OM di kawasan dataran rumput laut, seston mencatat nilai yang paling tinggi iaitu sebanyak 53 - 98\% (Rajah 2). Muara Sungai Pulai merupakan muara yang mempunyai pasang surut dataran rumput laut yang luas serta kedalaman air (2-3 meter) yang cetek. Persekitarannya merangkumi kawasan yang berlumpur dari bahagian bawah sehingga ke atas bahagian pertengahan di sekitar Sungai Jeram (De Troch et al. 2001). Tambahan lagi, ekosistem pesisir yang cetek bukan sahaja berfungsi sebagai zon peralihan antara darat dan laut namun ia juga mampu menyerap karbon yang tersekuester yang akan mengurangkan peningkatan kepekatan $\mathrm{CO}_{2}$ di atmosfera.

Karbon luaran atau aloktanus boleh diperoleh daripada flora daratan, habitat laut lain dan habitat sungai dan air tawar yang dipindahkan ke ekosistem karbon biru melalui aliran air dan arus udara (Kennedy et al. 2010; Watanabe \& Kuwae 2015) atau vektor haiwan (Reef et al. 2014). Menurut van Maren et al. (2014), muara di negeri Johor didominasi oleh sumber sedimen dari barat daya, dengan anggaran jumlah sedimen tahunan sebanyak 0.45 juta tan th $^{-1}$. Keadaan ini juga berpotensi untuk menjadi penyumbang terbesar sumber karbon aloktonus di kawasan muara Sungai Pulai. Oleh kerana muara Sungai Pulai dikuasai oleh arus pasang surut, ia mengandungi mendapan sedimen dan OM yang berasal dari daratan di sekitar mulut sungai (Shaari Hasrizal et al. 2017).

Kennedy et al. (2010) juga menyatakan bahawa dataran rumput laut yang terletak di teluk tertutup atau berhampiran dengan bakau, bahan organik aloktonus mungkin meningkat dan mampu menyumbang kepada peningkatan OM di kawasan tersebut. Tambahan lagi, aktiviti antropogenik yang sedang giat dijalankan di kawasan kajian juga mampu menyumbang kepada peningkatan sumber aloktonus. Kawasan kajian yang didominasi oleh spesies rumput laut Enhalus acoroides dan dataran rumput yang luas di muara Sungai Pulai menjadi sebab seston mencatat peratusan yang paling tinggi berbanding sumber penyumbang yang lain. Hal ini kerana morfologi bilah daun rumput laut Enhalus acoroides yang besar dan panjang juga menyumbang kepada pemerangkapan zarah terampai di dalam turus air. Apabila ombak menyebar ke atas dataran rumput laut, ombak dan halaju arus dikurangkan dan rumput laut ini mampu meningkatkan pemendapan bahan organik melalui pemerangkapan zarah seston oleh daun atau bilah rumput laut, dan ia juga mampu mengurangkan kapasiti bawaan zarah di dalam air di kawasan tersebut (Chen et al. 2014; Duarte et al. 2013; Folmer et al. 2012).

Di perairan tropika, makroalga sering dijumpai mendiami bersama tumbuhan persisiran yang lain dan membentuk hamparan makrofit yang bercampur (Short \& Frederick 2003) Makroalga yang terdapat di kawasan kajian mencatat nilai sumber penyumbang yang kedua tertinggi iaitu masing-masing sebanyak 28\% dan $23 \%$ di Merambong Timur dan Barat berbanding di Tanjung Adang iaitu $0.89 \%$ (Jadual 2). Meskipun rumput laut mendominasi kawasan kajian, makroalga mencatat nilai sumber peratusan penyumbang OM yang lebih tinggi berbanding rumput laut. Kajian terdahulu menunjukkan bahawa OM yang berasal daripada makroalga telah terendap serentak dengan rumput laut dan OM yang berasal dari bakau (Mazarrasa et al. 2015; Rozaimi et al. 2016; Serrano et al. 2016) dan pengeluar utama yang dominan di habitat pantai tidak semestinya menyumbang kepada takungan OM yang dominan.

Sumber penyumbang epifit mencatat nilai sumbangan yang lebih tinggi (11\%) berbanding sumber penyumbang rumput laut iaitu 7\% (Jadual 2). Meskipun rumput laut merupakan pengeluar utama di kawasan muara Sungai Pulai, hal ini tidak menjamin rumput laut sebagai sumber penyumbang yang tinggi kepada nilai OM. Epifit yang hidup di permukaan bilah daun rumput laut mengurangkan produktiviti makrofit dengan menghalang 
$\delta^{13} \mathrm{C}$
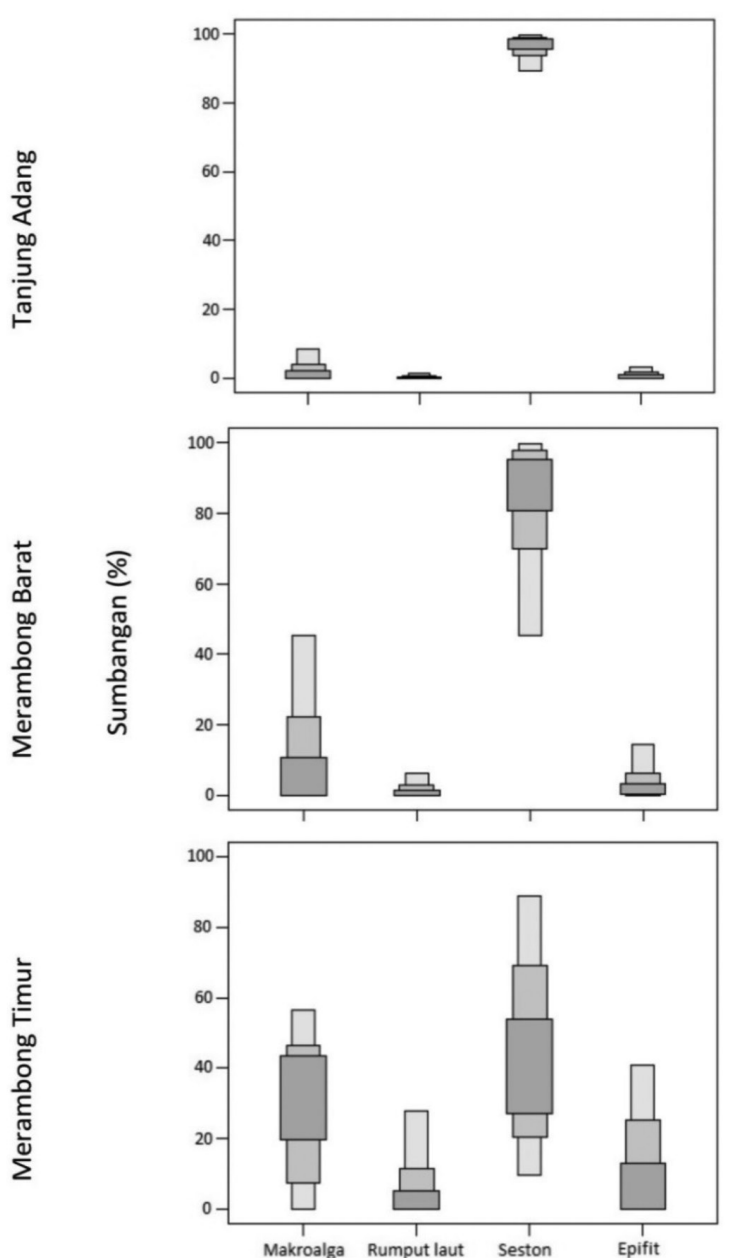

$\delta{ }^{13} \mathrm{C}$ dan $\delta{ }^{15} \mathrm{~N}$
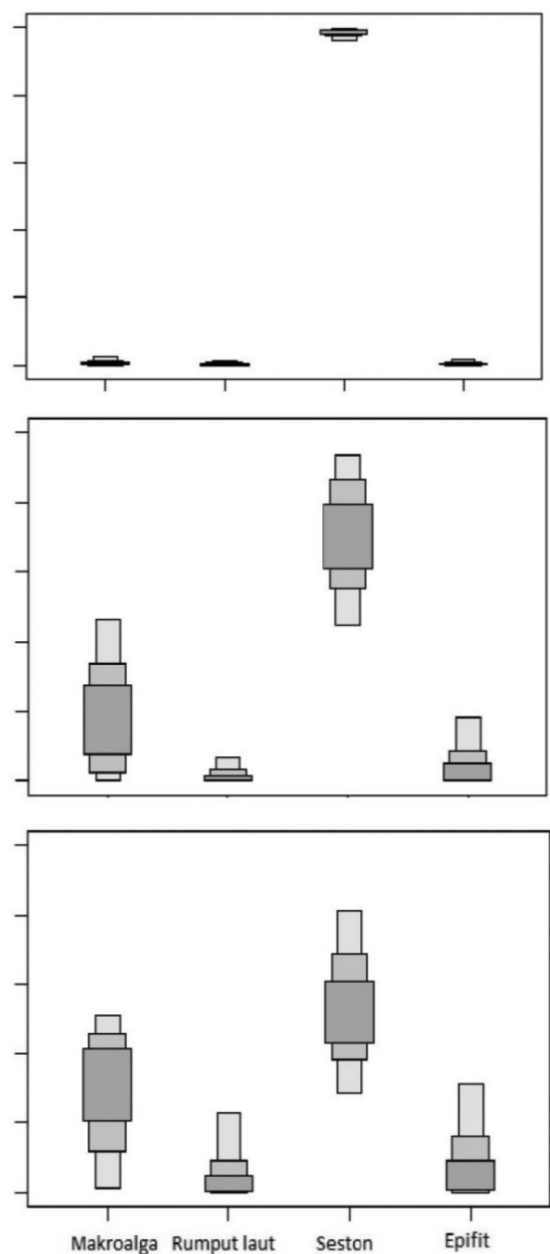

RAJAH 2. Plot ketumpatan berdasarkan penjujukan satu $\left(\delta^{13} \mathrm{C}\right)$ dan dua jenis isotop stabil $\left(\delta^{13} \mathrm{C}\right.$ dan $\delta^{15} \mathrm{~N}$ ) terhadap jenis sumbangan peratusan karbon di muara Sungai Pulai. Kotak yang berwarna kelabu gelap, kurang gelap dan seterusnya warna kelabu terang mewakili masingmasing 50\%, 75\% dan 95\% peratus julat kebolehpercayaan Bayesian (CI95\%)

JADUAL 2. Min perkadaran sumbangan sumber organik terhadap bahan organik (OM) pukal di dalam sedimen berdasarkan model percampuran Bayesian SIAR. CI95 merujuk kepada 95\% peratus kebolehpercayaan. (a) Model pencampuran Bayesian berdasarkan dua isotop $\left(\delta^{13} \mathrm{C}\right.$ dan $\left.\delta^{15} \mathrm{~N}\right)$; dan (b) model pencampuran berdasarkan nilai satu isotop $\left(\delta^{13} \mathrm{C}\right)$

(a)

\begin{tabular}{lcccccccc}
\hline & \multicolumn{2}{c}{ Makroalga } & \multicolumn{2}{c}{ Rumput laut } & \multicolumn{2}{c}{ Seston } & \multicolumn{2}{c}{ Epifit } \\
\cline { 2 - 8 } & Min $(\%)$ & CI95 $(\%)$ & Min $(\%)$ & CI95 (\%) & Min $(\%)$ & CI95 (\%) & Min $(\%)$ & CI95 (\%) \\
\hline Tanjung Adang & 0.89 & $0.00-2.47$ & 0.43 & $0.00-1.23$ & 98.15 & $96.18-99.82$ & 0.54 & $0.00-1.47$ \\
Merambong Barat & 23.17 & $0.00-47.54$ & 2.29 & $0.00-6.87$ & 68.51 & $42.84-93.67$ & 6.02 & $0.00-18.12$ \\
Merambong Timur & 28.23 & $0.77-51.78$ & 7.01 & $0.00-23.35$ & 53.38 & $27.38-81.91$ & 11.39 & $0.00-30.79$ \\
\hline
\end{tabular}

(b)

\begin{tabular}{lcccccccc}
\hline & \multicolumn{2}{c}{ Makroalga } & \multicolumn{2}{c}{ Rumput laut } & \multicolumn{2}{c}{ Seston } & \multicolumn{2}{c}{ Epifit } \\
\cline { 2 - 8 } & Min $(\%)$ & CI95 $(\%)$ & Min $(\%)$ & CI95 $(\%)$ & Min $(\%)$ & CI95 (\%) & Min (\%) & CI95 (\%) \\
\hline Tanjung Adang & 2.97 & $0.00-8.68$ & 0.58 & $0.00-1.62$ & 95.23 & $89.15-99.75$ & 1.21 & $0.00-3.43$ \\
Merambong Barat & 15.64 & $0.00-46.38$ & 2.06 & $0.00-6.07$ & 77.52 & $43.66-99.91$ & 4.78 & $0.00-14.87$ \\
Merambong Timur & 29.84 & $0.00-56.07$ & 8.29 & $0.00-27.41$ & 45.86 & $9.56-86.95$ & 16.01 & $0.00-40.64$ \\
\hline
\end{tabular}


dan mengurangkan ketersediaan nutrien ke dalam rumput laut (Bulthuis \& Woelkerling 1983; Neckles et al. 1993; Neundorfer \& Kemp 1993), sekaligus menapis $\mathrm{CO}_{2}$ daripada masuk secara terus ke permukaan bilah daun rumput laut. Hal ini menyebabkan epifit mampu menyumbang sumber karbon daratan yang lebih tinggi berbanding rumput laut (Harrison 1989).

Objektif yang kedua dalam kajian ini adalah membuat perbandingan penggunaan dua penjejak isotop stabil $\left(\delta^{13} \mathrm{C}\right.$ dan $\left.\delta^{15} \mathrm{~N}\right)$ dan penggunaan satu penjejak isotop stabil $\left(\delta^{13} \mathrm{C}\right)$ untuk menentukan sumber karbon di dalam dataran rumput laut. Dua penjejak isotop stabil $\left(\delta^{13} \mathrm{C}\right.$ dan $\left.\delta^{15} \mathrm{~N}\right)$ dan satu penjejak isotop stabil $\left(\delta^{13} \mathrm{C}\right)$ menunjukkan persamaan dalam penentuan nilai sumber penyumbang OM yang terbesar, namun berbeza dalam menunjukkan nilai julat peratus kebolehpercayaan CI95 (\%) bagi setiap sumber. Penggunaan dua penjejak isotop stabil $\left(\delta^{13} \mathrm{C}\right.$ dan $\left.\delta^{15} \mathrm{~N}\right)$ atau satu penjejak isotop stabil $\left(\delta^{13} \mathrm{C}\right)$, kedua-duanya masih menunjukkan seston sebagai sumber penyumbang yang terbesar kepada kandungan OM manakala sumber rumput laut menjadi penyumbang yang terkecil berbanding sumber-sumber lain di muara Sungai Pulai.

Meskipun begitu, graf ketumpatan yang diplotkan berdasarkan nilai julat peratus kebolehpercayaan (CI95\%) antara $\delta^{13} \mathrm{C}$ dan $\delta{ }^{15} \mathrm{~N}$, atau $\delta{ }^{13} \mathrm{C}$ sahaja, menunjukkan perbezaan daripada segi julat yang agak ketara bagi setiap sumber. Bagi Tanjung Adang, graf ketumpatan yang diplotkan menggunakan nilai peratus julat kebolehpercayaan (CI95\%) penanda isotop stabil $\delta^{13} \mathrm{C}$ dan $\delta^{15} \mathrm{~N}$ menunjukkan sumber seston mempunyai julat yang lebih kecil iaitu 96.2-99.8\% berbanding nilai peratus julat kebolehpercayaan (CI95\%) seston yang dicatatkan menggunakan satu penjejak isotop stabil $\delta^{13} \mathrm{C}$ sahaja iaitu 89.2-99.8\% (Jadual 2). Hal ini kerana penyumbang yang mempunyai julat yang lebih rendah pada graf ketumpatan memberikan nilai peratus sumbangan yang lebih dipercayai dalam hasil pemodelan tersebut. Nilai peratus julat kebolehpercayaan (CI95\%) isotop stabil $\delta^{13} \mathrm{C}$ dan $\delta^{15} \mathrm{~N}$ seston mencatat nilai julat yang lebih kecil berbanding nilai peratus julat kebolehpercayaan (CI95\%) isotop stabil $\delta^{13} \mathrm{C}$ bagi di Merambong Barat dan Merambong Timur.

Bagi Merambong Barat, nilai peratus julat kebolehpercayaan (CI95\%) bagi penjejak isotop stabil $\delta^{13} \mathrm{C}$ dan $\delta^{15} \mathrm{~N}$ menunjukkan sumber makroalga mempunyai julat yang lebih besar iaitu $0.0-47.5 \%$ berbanding nilai julat peratus kebolehpercayaan (CI95\%) makroalga yang dicatatkan menggunakan satu penjejak isotop stabil $\delta^{13} \mathrm{C}$ sahaja iaitu $0.0-46.4 \%$. Hal ini menunjukkan terdapat sesetengah julat peratus kebolehpercayaan (CI95\%) penggunaan dua penjejak isotop stabil $\left(\delta^{13} \mathrm{C}\right.$ dan $\left.\delta^{15} \mathrm{~N}\right)$ berjulat yang tinggi berbanding pengunaan satu penjejak isotop stabil $\left(\delta^{13} \mathrm{C}\right)$.

Meskipun begitu, secara keseluruhannya, kajian ini menunjukkan julat kebolehpercayaan untuk penggunaan satu penjejak isotop stabil $\left(\mathrm{\delta}^{13} \mathrm{C}\right)$ lebih besar berbanding julat penggunaan dua penjejak isotop stabil $\left(\delta^{13} \mathrm{C}\right.$ dan $\delta^{15} \mathrm{~N}$ ). Analisis statistik (ANOVA) telah membuktikan bahawa julat kebolehpercayaan (CI95) penggunaan dua penjejak isotop stabil $\left(\delta^{13} \mathrm{C}\right.$ dan $\left.\delta^{15} \mathrm{~N}\right)$ lebih bererti $(\mathrm{p}<0.05$; Jadual 3 ) berbanding julat kebolehpercayaan penggunaan satu penjejak isotop stabil $\left(\delta^{13} \mathrm{C}\right)$. Hal ini menunjukkan nilai julat kebolehpercayaan (CI95) yang kecil lebih tepat dalam menentukan peratus sumbangan sumber karbon berbanding nilai julat kebolehpercayaan (CI95) yang lebih besar. Penggunaan dua penjejak isotop stabil juga dibuktikan lebih tepat berbanding penggunaan satu penjejak isotop stabil sahaja.

Pendekatan isotop mungkin dapat berfungsi baik dengan menggunakan pelbagai penjejak dan perbandingan mungkin boleh dilakukan bagi persampelan pada masa dan ruang isotop yang luas (Fry 2013). Dengan membandingkan dua jenis penanda isotop $\left(\delta^{13} \mathrm{C}\right.$ dan $\left.\delta^{15} \mathrm{~N}\right)$, julat peratus kebolehpercayaan (CI95\%) menunjukkan nilai yang lebih kecil berbanding nilai julat peratus kebolehpercayaan yang ditunjukkan oleh isotop $\delta^{13} \mathrm{C}$ (Jadual $2 \&$ Rajah 2). Apabila nilai julat dan nilai min kecil, maka lebih mudah untuk mengetahui jumlah sebenar sumber karbon dan mengurangkan ralat dalaman dan ketidakpastian dalam data kajian.

Akhir sekali, penggunaan satu penjejak isotop stabil $\left(\delta^{13} \mathrm{C}\right)$ sudah memadai dalam mengetahui peratusan sumbangan sumber OM. Namun julat kebolehpercayaan (CI95) yang diberikan adalah lebih besar berbanding penggunaan dua penjejak isotop stabil $\left(\delta^{13} \mathrm{C}\right.$ dan $\left.\delta^{15} \mathrm{~N}\right)$. Meskipun penggunaan dua penjejak isotop stabil lebih tepat oleh kerana julat kebolehpercayaan (CI95) yang diberikan kecil, penggunaan beberapa isotop stabil ternyata lebih mahal (Fry 2013) berbanding penggunaan satu jenis isotop stabil sahaja. Penggunaan jenis dua penjejak isotop stabil atau jenis satu penjejak isotop dalam mengetahui peratusan sumbangan OM juga bergantung kepada reka bentuk kajian. Jika ketepatan dalam julat kebolehpercayaan

JADUAL 3. Keputusan analisis ANOVA yang dijalankan untuk menentukan julat kebolehpercayaan antara dua kaedah (dua isotop stabil berbanding satu isotop stabil) penjujukan sumber. Sumber bahan organik merujuk kepada nilai $\delta^{13} \mathrm{C}$ sampel (rumput laut, seston, makroalga dan epifit) yang dikumpul dari tiga lokasi

\begin{tabular}{lcccc}
\hline Variasi sumber & SS & df & MS & F \\
\hline Julat $\delta^{13} \mathrm{C} \& \delta^{15} \mathrm{~N} \times$ Julat $\delta^{13} \mathrm{C}$ & 3510.08 & 1 & 3510.38 & 93.454 \\
Sumber bahan organik & 77.815 & 3 & 25.938 & 0.691 \\
\hline
\end{tabular}

*perbezaan bererti; NS perbezaan tidak bererti $(\mathrm{p}>0.05)$

$\mathrm{df}=$ darjah kebebasan, $\mathrm{SS}=$ hasil tambah kuasa dua, $\mathrm{MS}=$ min kuasa dua, $\mathrm{F}=$ nisbah $\mathrm{f}$ 
(CI95) yang diutamakan, maka penggunaan dua penjejak isotop stabil $\left(\delta^{13} \mathrm{C}\right.$ dan $\left.\delta^{15} \mathrm{~N}\right)$ dicadangkan sebagai lebih sesuai berbanding penggunaan satu penjejak isotop stabil $\left(\delta^{13} \mathrm{C}\right)$.

\section{KESIMPULAN}

Seston didapati menjadi sumber penyumbang OM yang dominan di dalam sedimen, dan mempunyai peratusan paling tinggi berbanding makroalga, epifit dan rumput laut di kawasan dataran rumput laut di muara Sungai Pulai. Hal ini disebabkan oleh faktor geografi kawasan kajian yang dekat dengan muara sungai; sumber aloktonus daripada luar yang masuk ke muara sungai dan juga pertambahan sumber aloktonus daripada aktiviti antropogenik yang sedang giat dijalankan di kawasan tersebut. Pendekatan penggunaan satu penjejak isotop ataupun dua penjejak isotop dipilih berdasarkan tujuan kajian yang dilakukan. Penggunaan satu penjejak isotop $\left(\delta^{13} \mathrm{C}\right)$ boleh digunakan dalam mengenal pasti sumber karbon manakala penggunaan dua penjejak isotop yang pelbagai akan mengenal pasti sumber bahan organik dengan lebih tepat. Ini kerana julat kebolehpercayaan (CI95) dan min penanda di antara sumber lebih kecil dan jelas dilihat jika menggunakan dua penjejak penanda isotop $\left(\delta^{13} \mathrm{C}\right.$ dan $\left.\delta^{15} \mathrm{~N}\right)$ berbanding satu penjejak penanda isotop $\left(\delta^{13} \mathrm{C}\right)$.

\section{PENGHARGAAN}

Setinggi-tinggi penghargaan kepada Universiti Kebangsaan Malaysia untuk geran UKM-GUP-2018-031 yang diberikan oleh bagi menjalankan kajian ini.

\section{RUJUKAN}

Ahmad, F., Azman, S., Said, M.I.M. \& Lavania-Baloo. 2015. Tropical seagrass as a bioindicator of metal accumulation. Sains Malaysiana 45(1): 203-210.

Ara, R., Arshad, A., Amin, S.N., Daud, S.K. \& Ghaffar, M.A. 2011. Environment and diversity of ichthyoplankton in the seagrass beds of Sungai Pulai estuary, Johor, Peninsular Malaysia. Journal of Food, Agriculture and Environment 9(3\&4): 733-738.

Arshad,A.,Amin, S.N. \& Osman, N. 2010. Population parameters of planktonic shrimp, Lucifer intermedius (Decapoda: Sergestidae) from Sungai Pulai Seagrass Area Johor, Peninsular Malaysia. Sains Malaysiana 39(6): 877-882.

Belicka, L.L. \& Harvey, H.R. 2009. The sequestration of terrestrial organic carbon in arctic ocean sediments: A comparison of methods and implications for regional carbon budgets. Geochimica et Cosmochimica Acta 73(20): 62316248 .

Benstead, J.P., March, J.G., Fry, B., Ewel, K.C. \& Pringle, C.M. 2006. Testing isosource: Stable isotope analysis of a tropical fishery with diverse organic matter sources. Ecology 87(2): 326-333.

Bouillon, S. \& Boschker, H.T.S. 2006. Bacterial carbon sources in coastal sediments: A cross-system analysis based on stable isotope data of biomarkers. Biogeosciences 3(2): 175-185.
Briand, M.J., Bonnet, X., Goiran, C., Guillou, G. \& Letourneur, Y. 2015. Major sources of organic matter in a complex coral reef lagoon: Identification from isotopic signatures $\left(\delta^{13} \mathrm{C}\right.$ and $\left.\delta^{15} \mathrm{~N}\right)$. PLOS ONE 10(7): e 0131555.

Bulthuis, D.A. \& Woelkerling, W.J. 1983. Biomass accumulation and shading effects of epiphytes on leaves of the seagrass, Heterozostera Tasmanica, in Victoria, Australia. Aquatic Botany 16(2): 137-148.

Cob, Z.C., Arshad, A., Bujang, J.S. \& Ghaffar, M.A. 2014. Spatial and temporal variations in Strombus canarium (Gastropoda: Strombidae) abundance at Merambong seagrass bed, Malaysia. Sains Malaysiana 43(4): 503-511.

Chen, G.C., Ulumuddin, Y.I., Pramudji, S., Chen, S.Y., Chen, B., Ye, Y., Ou, D.Y., Ma, Z.Y., Huang, H. \& Wang, J.K. 2014. Rich soil carbon and nitrogen but low atmospheric greenhouse gas fluxes from north sulawesi mangrove swamps in Indonesia. Science of the Total Environment 487: 91-96.

Collins, A.L., Walling, D.E., Webb, L. \& King, P. 2010. Apportioning catchment scale sediment sources using a modified composite fingerprinting technique incorporating property weightings and prior information. Geoderma $155(3$ 4): 249-261.

Dauby, P. 1989. The stable carbon isotope ratios in benthic food webs of the Gulf of Calvi, Corsica. Continental Shelf Research 9(2): 181-195.

De Troch, M., Gurdebeke, S., Fiers, F. \& Vincx, M. 2001 Zonation and structuring factors of meiofauna communities in a tropical seagrass bed (Gazi Bay, Kenya). Journal of Sea Research 45(1): 45-61.

Duarte, C.M. \& Cebrián, J. 1996. The fate of marine autotrophic production. Limnology and Oceanography 41(8): 1758-1766.

Duarte, C.M., Kennedy, H., Marbà, N. \& Hendriks, I. 2013. Assessing the capacity of seagrass meadows for carbon burial: Current limitations and future strategies. Ocean and Coastal Management 83: 32-38.

Duarte, C.M., Marbà, N., Gacia, E., Fourqurean, J.W., Beggins, J., Barrón, C. \& Apostolaki, E.T. 2010. Seagrass community metabolism: Assessing the carbon sink capacity of seagrass meadows. Global Biogeochemical Cycles 24(4): GB4032.

Duarte, C.M., Middelburg, J.J. \& Caraco, N. 2005. Major role of marine vegetation on the oceanic carbon cycle. Biogeosciences 2(1): 1-8.

Fairoz, M., Rozaimi, M. \& Nastasia, W.F. 2018. Records of sea star (Echinodermata, Asteroidea) diversity in a disturbed tropical seagrass meadow. Arxius de Miscel-lània Zoològica 16: 243-254.

Folmer, E.O., van der Geest, M., Jansen, E., Olff, H., Anderson, T.M., Piersma, T. \& van Gils, J.A. 2012. Seagrass-sediment feedback: An exploration using a non-recursive structural equation model. Ecosystems 15(8): 1380-1393.

Fry, B. 2013. Alternative approaches for solving underdetermined isotope mixing problems. Marine Ecology Progress Series 472: 1-13.

Fry, B. \& Sherr, E.B. 1984. $\delta^{13}$ C measurements as indicators of carbon flow in marine and freshwater ecosystems. Contributions in Marine Science 27: 13-27.

Fry, B., Scalan, R.S. \& Parker, P.L. 1977. Stable carbon isotope evidence for two sources of organic matter in coastal sediments: Seagrasses and plankton. Geochimica et Cosmochimica Acta 41(12): 1875-1877.

Gacia, E. \& Duarte, C.M. 2001. Sediment retention by a mediterranean posidonia oceanica meadow: The balance between deposition and resuspension. Estuarine, Coastal and Shelf Science 52(4): 505-514. 
Gacia, E., Duarte, C.M. \& Middelburg, J.J. 2002. Carbon and nutrient deposition in a mediterranean seagrass (Posidonia oceanica) meadow. Limnology and Oceanography 47(1): 23-32.

Greiner, J.T., Wilkinson, G.M., McGlathery, K.J.\& Emery, K.A. 2016. Sources of sediment carbon sequestered in restored seagrass meadows. Marine Ecology Progress Series 551: 95-105.

Harrison, P.G. 1989. Detrital processing in seagrass systems: A review of factors affecting decay rates, remineralization and detritivory. Aquatic Botany 35(3-4): 263-288.

Hidayah, N., Tahirin, S.A., Fairoz, M. \& Rozaimi, M. 2019. Carbon stock and $\delta 13 \mathrm{C}$ data of sediment samples collected from a tropical seagrass meadow in Malaysia. Plant Science Today 6(2): 132-136.

Hossain, M.S., Hashim, M., Bujang, J.S., Zakaria, M.H. \& Muslim, A.M. 2018. Assessment of the impact of coastal reclamation activities on seagrass meadows in Sungai Pulai Estuary, Malaysia, using Landsat data (1994-2017). International Journal of Remote Sensing 1161: 1-35.

Kadoya, T., Yutaka, O. \& Gaku, T. 2012. Isoweb: A bayesian isotope mixing model for diet analysis of the whole food web. PLOS ONE 7(7): e41057.

Kennedy, H., Beggins, J., Duarte, C.M., Fourqurean, J.W., Holmer, M., Marbá, N. \& Middelburg, J.J. 2010. Seagrass sediments as a global carbon sink: Isotopic constraints. Global Biogeochemical Cycles 24(4): GB4026.

Krull, E., Haynes, D., Lamontagne, S., Gell, P., McKirdy, D., Hancock, G., McGowan, J. \& Smernik, R. 2009. Changes in the chemistry of sedimentary organic matter within the coorong over space and time. Biogeochemistry 92(1-2): 9-25.

Lavery, P.S., Mateo, M.A., Serrano, O. \& Rozaimi, M. 2013. Variability in the carbon storage of seagrass habitats and its implications for global estimates of blue carbon ecosystem service. PLOS ONE 8(9): e73748.

Lee, K.M., Lee, S.Y. \& Connolly, R.M. 2012. Combining process indices from network analysis with structural population measures to indicate response of estuarine trophodynamics to pulse organic enrichment. Ecological Indicators 18: 652-658.

Mazarrasa, I., Marbà, N., Lovelock, C.E., Serrano, O., Lavery, P.S., Fourqurean, J.W., Kennedy, H., Mateo, M.A., KrauseJensen, D., Steven, A.D.L. \& Duarte, C.M. 2015. Seagrass meadows as a globally significant carbonate reservoir. Biogeosciences 12(5): 4107-4138.

Minagawa, M. 1992. Reconstruction of human diet from $\Sigma 13 C$ and $\Sigma 15 \mathrm{~N}$ in contemporary japanese hair: A stochastic method for estimating multi-source contribution by double isotopic tracers. Applied Geochemistry 7(2): 145-158.

Neckles, H.A., Wetzel, R.L. \& Orth, R.J. 1993. Relative effects of nutrient enrichment and grazing on epiphyte-macrophyte (Zostera marina L.) dynamics. Oecologia 93(2): 285-295.

Neundorfer, J.V. \& Kemp, W.M. 1993. Nitrogen versus phosphorus enrichment of brackish waters: Responses of the submersed plant Potamogeton Perfoliatus and its associated algal community. Marine Ecology Progress Series 94(1): 71-82.

Parnell, A.C., Inger, R., Bearhop, S. \& Jackson, A.L. 2010. Source partitioning using stable isotopes: Coping with too much variation. PLOS ONE 5(3): e9672.

Peterson, B.J. 1999. Stable isotopes as tracers of organic matter input and transfer in benthic food webs: A review. Acta Oecologica 20(4): 479-487.
Phillips, D.L. 2012. Converting isotope values to diet composition: The use of mixing models. Journal of Mammalogy 93(2): 342-352.

Phillips, D.L. \& Gregg, J.W. 2003. Source partitioning using stable isotopes: Coping with too many sources. Oecologia 136(2): 261-269.

Phillips, D.L., Newsome, S.D. \& Gregg, J.W. 2005. Combining sources in stable isotope mixing models: Alternative methods. Oecologia 144(4): 520-527.

Reef, R., Feller, I.C. \& Lovelock, C.E. 2014. Mammalian herbivores in Australia transport nutrients from terrestrial to marine ecosystems via mangroves. Journal of Tropical Ecology 30(3): 179-188.

Rozaimi, M., Lavery, P.S., Serrano, O. \& Kyrwood, D. 2016. Long-term carbon storage and its recent loss in an estuarine Posidonia australis meadow (Albany, Western Australia). Estuarine, Coastal and Shelf Science 171: 58-65.

Schauer, J.J., Rogge, W.F., Hildemann, L.M., Mazurek, M.A., Cass, G.R. \& Simoneit, B.R. 1996. Source apportionment of airborne particulate matter using organic compounds as tracers. Atmospheric Environment 30(22): 3837-3855.

Serrano, O., Ricart, A.M., Lavery, P.S., Mateo, M.A., AriasOrtiz, A., Masque, P., Steven, A. \& Duarte, C.M. 2016. Key biogeochemical factors affecting soil carbon storage in Posidonia meadows. Biogeosciences 13(15): 4581-4594.

Shaari, H., Shazili, N.A.M., Abdullah, L.I. \& Abdullah, N.A. 2017. Geochemistry and clay minerals of surface sediments of southwestern Johor, Malaysia. Malaysian Journal of Analytical Science 21(2): 312-322.

Shi, G.W., Mazlan, A.G., Md Ali, M. \& Che Cob, Z. 2014. The Polychaeta (Annelida) communities of the Merambong and Tanjung Adang Shoals, Malaysia, and its relationship with the environmental variables. Malayan Nature Journal 66(12): $168-183$.

Short, F.T. \& Frederick, T. 2003. World Atlas of Seagrasses. Volume 41. Berkeley: University of California Press.

Smit, A.J., Brearley, A., Hyndes, G.A., Lavery, P.S. \& Walker, D.I. 2005. Carbon and nitrogen stable isotope analysis of an Amphibolis griffithii seagrass bed. Estuarine, Coastal and Shelf Science 65(3): 545-556.

Stock, B.C. \& Semmens, B.X. 2016. MixSIAR GUI User Manual. Version 3.1: 1-42 https:/github.com/brianstock/MixSIAR/. doi: 10.5281/zenodo.47719. Accessed in October 2013.

van Maren, D.S., Liew, S.C. \& Hasan, G.J. 2014. The role of terrestrial sediment on turbidity near Singapore's coral reefs. Continental Shelf Research 76: 75-88.

Watanabe, K. \& Kuwae, T. 2015. How organic carbon derived from multiple sources contributes to carbon sequestration processes in a shallow coastal system? Global Change Biology 21(7): 2612-2623.

Zencich, S.J., Froend, R.H., Turner, J.V. \& Gailitis, V. 2002. Influence of groundwater depth on the seasonal sources of water accessed by Banksia tree species on a shallow, sandy coastal aquifer. Oecologia 131(1): 8-19.

Nur Hidayah, Mohammad Rozaimi* \& Mohd Shahrul Mohd Nadzir

Center for Earth Sciences and Environment

Faculty of Science and Technology

Universiti Kebangsaan Malaysia

43600 UKM Bangi, Selangor Darul Ehsan

Malaysia 
Mohd Shahrul Mohd Nadzir

Centre for Tropical Climate Change System Institute of Climate Change

Universiti Kebangsaan Malaysia

43600 UKM Bangi, Selangor Darul Ehsan

Malaysia
*Pengarang untuk surat-menyurat; email: mdrozaimi@ukm. edu.my

Diserahkan: 25 Mac 2019

Diterima: 15 Ogos 2019 